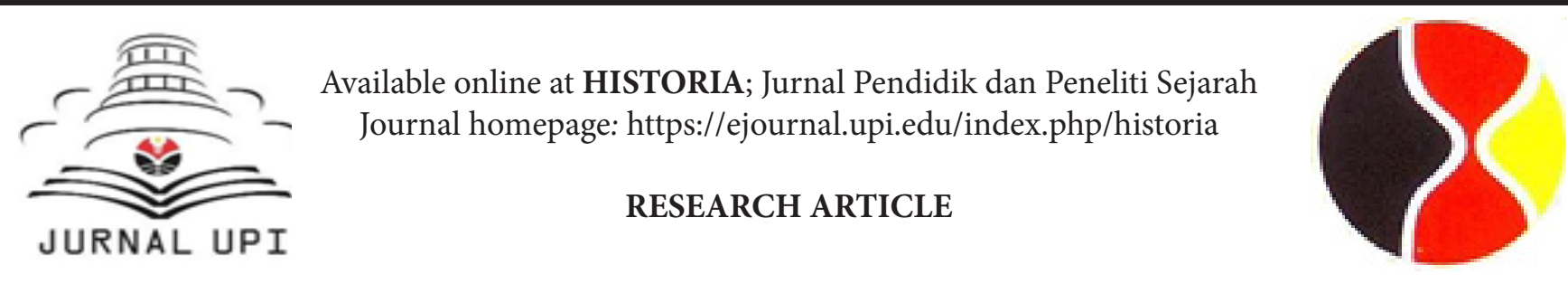

\title{
PEMANFAATAN PENGALAMAN SEJARAWAN UNTUK MENINGKATKAN KETERAMPILAN PESERTA DIDIK DALAM PENELITIAN SEJARAH
}

\author{
Labibatussolihah \\ Departemen Pendidikan Sejarah, FPIPS, Universitas Pendidikan Indonesia (UPI) \\ labibatussolihah@upi.edu
}

To cite this article: Labibatussolihah. (2020). Pemanfaatan pengalaman sejarawan untuk meningkatkan keterampilan peserta didik dalam penelitian sejarah. HISTORIA: Jurnal Pendidik dan Peneliti Sejarah, 3(1), 11-20. https://doi.org/10.17509/ historia.v3i1.19525.

Naskah diterima : 28 Agustus 2019, Naskah direvisi : 26 November 2019, Naskah disetujui : 30 Desember 2019

\begin{abstract}
In this era when technological advances make students vulnerable to unverified information, hoax, history learning has an important role in stimulating their criticism and literacy skills. Students understanding in the historical method which is consists of heuristics, criticism, interpretation, and art of historical writing as an effective working tool should be pursued one of them by obtaining such knowledge from historian's experience presented in the learning process. This study uses the classroom action research method with Elliot's design to answer the problem of how to improve students' abilities in historical research through the use of historian's experience? From this study it can be concluded 1) there is increase in historical research skills after the students get material historian experience; 2) it also increase students' criticism in choosing sources of reference; 3 ) history learning becomes more interesting and challenging for students.
\end{abstract}

Keywords: historian; historical method; history learning; historical research.

\begin{abstract}
Abstrak
Dalam era kemajuan teknologi informasi dimana kemudahan komunikasi membuat peserta didik rentan terpapar informasiinformasi yang tidak jelas kebenarannya, hoax, pembelajaran sejarah memiliki peran penting dalam meningkatkan kritisme dan kemampuan literasi. Penguasaan siswa dalam metode sejarah; terdiri atas heuristik, kritik, interpretasi, dan historiografi, sebagai alat kerja yang efektif perlu diupayakan salah satunya dengan mendapatkan pengetahuan tersebut dari sejarawan yang dihadirkan dalam pembelajaran. Studi ini menggunakan metode Penelitian Tindakan Kelas dengan desain Elliot untuk menjawab masalah bagaimana peningkatan kemampuan peserta didik dalam penelitian sejarah melalui pemanfaatan pengalaman sejarawan? Dari penelitian ini dapat disimpulkan 1) terjadi peningkatan keterampilan penelitian sejarah setelah peserta didik mendapat materi pengalaman sejarawan; 2) meningkatnya kritisme peserta didik dalam memilih sumber rujukan informasi; 3) pembelajaran sejarah menjadi lebih menarik dan menantang bagi peserta didik.
\end{abstract}

Kata Kunci: Metode sejarah; pembelajaran sejarah; penelitian sejarah; sejarawan. 


\section{PENDAHULUAN}

Penelitian ini diawali dari keresahan peneliti karena keterlibatan langsung sejarawan dalam proses pembelajaran sejarah masih minim untuk dikaji. Penelitian lebih banyak membahas tentang peran sejarawan sebagai profesi yang menantang dalam melakukan penelusuran fakta sejarah. Penelitian tentang pelibatan sejarawan dalam proses pembelajaran telah dilakukan oleh mahasiswa di Massachusetts College of Art yang sedang belajar melakukan penelitian sejarah yang biasa dilakukan oleh sejarawan (Korzenik, 1985; Haigh, 2012). Pembelajaran sejarah menjadi lebih menyenangkan namun penelitian tersebut fokus kepada kegiatan sejarawan dan mahasiswa yang melakukan penelitian sejarah. Penelitian tersebut belum menjadikan sejarawan sebagai sumber belajar yang memberikan pengalamananya dalam melakukan penelitian dengan berinteraksi langsung kepada peserta didik yang menjadikan pembelajaran sejarah bermakna.

Sedangkan Viator (2012) melakukan penelitian mengenai keterampilan berpikir sejarah di sekolah menengah. Riset bertujuan menjadikan peserta didik kritis melalui pertanyaan-pertanyaan yang diajukan. Konsep berpikir sejarah dalam penelitian tersebut masih umum, perlu cakupan yang lebih spesifik dan mendalam. Dengan demikian, penelitian ini terfokus pada keterampilan penelitian sejarah yang merupakan salah satu keterampilan yang dikembangkan dari berpikir sejarah dengan memanfaatkan pengalaman sejarawan sebagai sumber belajar.

Pembelajaran merupakan proses interaksi antara guru, peserta didik dan lingkungannya. Guru memiliki tugas menyusun rencana pembelajaran untuk tercapainya tujuan pembelajaran yang diharapkan. Permasalahan yang dihadapi oleh guru di kelas biasanya mengenai kurangnya memanfaatkan sumber belajar, model pembelajaran maupun strategi pembelajaran. Akibatnya pembelajaran sering dicap menjenuhkan dan akan menjadikan peserta didik mengalami kesulitan dalam mencapai tujuan yang telah dirancang oleh guru. Padahal mata pelajaran sejarah memiliki peran yang sangat strategis dalam menanamkan nasionalisme bagi peserta didik yang merupakan bagian dari bangsa Indonesia yang mengalami perjalanan sejarah yang panjang sampai mencapai kemerdekaan.

Pembelajaran sejarah yang secara umum telah memiliki kesan membosankan tersebut disebabkan oleh kegiatan pembelajaran yang kurang menarik dan pembahasan terfokus kepada fakta-fakta sejarah seperti tahun, nama tokoh, dan nama tempat. Padahal pembelajaran sejarah tidak terbatas hanya pada fakta melainkan memaknai dari setiap peristiwanya. Faktafakta sejarah tersebut perlu untuk dihubungkan menjadi satu rangkaian sehingga dapat menghasilkan interpretasi yang bermakna baru. Sebagaimana yang diutarakan oleh McCully (2012, hlm. 149)

Rather, the often engaged in quite a complex process in which they combined multiple sources of historical information in order to develop their own historical understandings that were never simply mirror of any one of those source.

Sebagai contoh dalam materi kehidupan awal manusia Indonesia, kegiatan yang umum dilakukan terbatas pada jenis manusia, ciri fisik dan pola kehidupannya. Hal tersebut menggambarkan bahwa pembelajaran sejarah di kelas terbatas pada fakta-fakta yang terpisah. Padahal melalui materi tersebut peserta didik dapat memaknai kontinuitas dalam sejarah seperti peralihan kehidupan manusia dari setiap zaman yang kemudian melalui peninggalannya dikaitkan dengan dampak kehidupan manusia masa kini. Upaya mencari sumber yang dilakukan peserta didik dapat melatih keterampilan dalam memperoleh informasi. Lingkungan sekitar sekolah maupun rumah peserta didik dapat dimanfaatkan untuk melatih keterampilan memperoleh informasi dari berbagai sumber. Proses pembelajaran yang belum terfokus pada keterampilan perlu untuk dilakukan perbaikan.

Penelitian-penelitian sebelumnya menunjukkan terdapat beberapa upaya yang telah dilakukan untuk menjadikan pembelajaran sejarah lebih menarik melalui beberapa cara seperti penggunaan media, metode dan model pembelajaran yang kreatif-inovatif. Meskipun terdapat upaya dalam memperbaiki proses pembelajaran namun masih sedikit yang memanfaatkan pengalaman sejarawan sebagai sumber belajar dalam pembelajaran sejarah.

Sejarawan yang telah memiliki pengalaman dalam melakukan penelitian sejarah dapat dijadikan sebagai salah satu alternatif sumber belajar. Melakukan konsultasi terkait calon penelitian peserta didik kepada sejarawan akan memperkaya informasi, wawasan dan pengalamannya. Sehingga masukan-masukan yang diberikan oleh para sejarawan dapat dijadikan bahan pertimbangan dalam mengembangkan penulisan sejarah atau historiografi secara sederhana.

Keterampilan dalam memperoleh informasi perlu dikembangkan karena akan bermanfaat bagi dirinya dalam menghadapi era globalisasi. Era informasi global yang mempercepat arus masuknya budaya baru dapat 
HISTORIA: Jurnal Pendidik dan Peneliti Sejarah, 3(1), 11-20. DOI: https://doi.org/10.17509/historia.v3i1.19525.

menyebabkan terjadinya kebingungan masyarakat dalam memberikan jawaban yang tepat (Wiriaatmadja, dalam Supriatna, 2007, hlm. 132). Teknologi yang berkembang saat ini menjadikan kehidupan manusia menjadi lebih praktis, termasuk dalam memperoleh informasi. Padahal informasi tersebut belum tentu kebenarannya, untuk itu manusia perlu cerdas dan kritis terhadap informasi yang diperoleh. Sebagaimana yang diungkapkan Supriatna (2007, hlm. 132) bahwa dalam menghadapi arus informasi yang demikian deras itu diperlukan keterampilan untuk memilih, menyeleksi, dan mengolah serta menggunakan informasi untuk memberdayakan dirinya. Membaca informasi yang diperoleh secara kritis dapat menghindari mudahnya penyebaran berita bohong atau hoax yang dapat memicu hate space.

Berdasarkan hasil pengamatan, cara guru mengajar masih terbatas pada pemahaman akan materi, belum kepada mempraktekannya dalam kehidupan seharihari. SMAN 3 Bandung sebagai sekolah yang unggul menunjukkan adanya peserta didik yang memiliki rasa percaya diri yang berlebih justru akan membawa dampak negatif seperti memunculkan sikap arogan merasa mengetahui segalanya. Peserta didik dalam menambah wawasannya untuk mengerjakan tugas yang diberikan guru sering kali menggunakan internet. Padahal penulis yang terdapat dalam situs internet tidak diketahui secara jelas latar belakangnya, namun peserta didik secara umum percaya akan tulisannya. Kepercayaan tersebut menunjukkan belum adanya sikap kritis terhadap sumber bacaan.

Literasi peserta didik tinggi namun sedikit yang berminat dalam membaca buku sejarah. Hal ini berdampak akan melunturnya pengenalan identitas diri sebagai bangsa Indonesia. Kekhawatiran ini sejalan dengan Rahayu (2019) yang menyebutkan peserta didik sekarang sebagai generasi $\mathrm{Z}$ yang hidup ditengah teknologi yang serba terhubung ke internet sehingga dapat menjadikannya hilang identitas diri. Padahal proses pengenalan identitas diri ini merupakan hal yang penting agar muncul rasa memiliki, bangga dan mencintai tanah air. Sebagaimana yang diungkapkan oleh Wiriaatmadja, (2002, hlm. 157) bahwa proses pengenalan diri inilah yang merupakan titik awal dari timbulnya rasa harga diri, kebersamaan, dan keterikatan (sense of solidarity), rasa keterpautan dan rasa memiliki (sense of belonging), kemudian rasa bangga (sense of pride) terhadap bangsa dan tanah air sendiri. Pelajaran sejarah memiliki peran strategis dalam kurikulum nasional untuk membangun cinta tanah air.
Kurikulum nasional yang berlaku yaitu kurikulum 2013 yang menekankan pada ranah pengetahuan, keterampilan dan sikap. Kompetensi inti (KI) dalam pelajaran sejarah dapat disimpulkan bahwa pelajaran sejarah berperan untuk mengembangkan wawasan kebangsaan, menghubungkan sebab akibat suatu kejadian, serta menyalurkan rasa ingin tahu peserta didik melalui penerapan pengetahuan prosedur dalam kehidupan sehari-hari untuk memcahkan masalah. Pendekatan yang berlaku dalam kurikulum yaitu menggunakan pendekatan scientific dalam proses pembelajaran. Pendekatan ini memposisikan peserta didik yang menemukan sendiri dan guru sebagai motivator untuk meningkatkan keterampilan penelitian peserta didik. Memanfaatkan sejarawan dengan menceritakan pengalamannya dapat membantu peserta didik memperoleh pengalaman belajar yang bermakna bagi dirinya. Pentingnya mengajak peserta didik untuk peka dan sadar akan lingkungan sekitar yang kaya akan sumber belajar dapat menjadikan peserta didik lebih aktif dalam memperoleh pengetahuan selama proses pembelajaran. Bekal inilah yang kemudian dapat digunakan untuk melakukan penelitian sejarah dengan menggunakan metode sejarah yang pertama kali diperkenalkan oleh Gottschlak. Metode sejarah disini adalah proses menguji dan menganalisis secara kritis rekaman dan peninggalan masa lampau (Gottschlak, 1985, hlm.39).

Lebih lanjut dijelaskan bahwa metode sejarah bersifat ilmiah karena mampu menentukan fakta yang diperoleh melalui pemeriksaan kritis terhadap dokumen sejarah. Dalam metode penelitian sejarah terdapat empat langkah yaitu heuristik, kritik, interpretasi dan historiografi. Pembelajaran sejarah dengan mengembangkan potensi yang terdapat dalam diri peserta didik dapat mengasah keterampilannya untuk dapat bersaing dalam menghadapi masa yang akan datang melalui keterampilan penelitian sejarah. Dengan demikian yang menjadi rumusan masalah utama dalam penelitian ini adalah "Bagaimana meningkatkan keterampilan peserta didik dalam penelitian sejarah melalui pemanfaatan pengalaman sejarawan ?"

\section{Pemanfaatan Pengalaman Sejarawan dalam Pembelajaran Sejarah}

Pembelajaran sejarah merupakan suatu proses kegiatan belajar mengajar pada mata pelajaran sejarah. Sebelum masuk ke dalam proses belajar mengajar maka diperlukan perencanaan pembelajaran agar tujuan belajar yang diharapkan dapat tercapai. Pembelajaran sejarah pada tingkat SMA, diharapkan peserta didik mampu 
untuk mengembangkan kemampuan berpikir yang lebih terarah dan memahami peristiwa sejarah secara mendalam. Sebagaimana yang diungkapkan oleh Hasan (2012, hlm. 7) bahwa pendidikan sejarah di SMA sudah lebih terarah kepada persiapan bagi mereka yang akan melanjutkan ke perguruan tinggi. Proses pembelajaran sejarah akan lebih mengembangkan pada kemampuan berpikir yang terencana dan lebih mendalam. Diperlukan perencanaan untuk mengembangkan kemampuan berpikir secara mendalam dengan memanfaatkan sumber belajar, terlebih pelajaran sejarah kaya akan materi mulai dari sejarah lokal sampai sejarah dunia.

Sumber belajar adalah segala sesuatu yang dapat dimanfaatkan oleh siswa untuk mempelajari bahan dan pengalaman belajar sesuai dengan tujuan yang hendak dicapai (Sanjaya, 2012, hlm. 174). Sumber belajar dalam pelajaran sejarah dapat diperoleh dengan menandatangkan sejarawan yang merupakan ahli sejarah atau penulis sejarah. Hasil rekonstruksi peristiwa sejarah masa lampau dikomunikasikan kepada pembaca saat ini melalui sejarawan. Sebagaimana Maslow (dalam Purwanto, hlm. 31, 2001) menjelaskan bahwa sejarah tidak hanya sekedar pengkajian tentang perubahan dalam konteks waktu melainkan sejarah merupakan pengkajian tentang informasi atau pengetahuan yang dihasilkan oleh sejarawan. Sejarawan bukanlah pengacara karena bekerja berdasarkan fakta dengan menjadikan dirinya untuk melakukan kritik dan konsisten dalam berpikir ulang akan temuan yang sudah dilakukan, adanya pemahaman yang lebih jelas dalam menulis sejarah melalui penelitian dan menginspirasi seperti John

\section{Dunn dan Quentin Skinner yang menginspirasi Burrow} (Cuttica, 2019).

Sejarawan membagi pengalamannya ketika melakukan penelitian sejarah yang erat kaitannya dengan metode sejarah, menurut Sjamsuddin (2007, hlm. 13) metode ada hubungannya dengan suatu prosedur, proses, atau teknik yang sistematis dalam penyelidikan suatu disiplin ilmu tertentu untuk mendapatkan objek (bahan-bahan) yang diteliti. Pengalaman sejarawan yang dimaksud adalah kegiatan yang telah dilakukan atau dialami seorang ahli sejarah dalam melakukan penelitian sejarah dengan menceritakannya kepada audiance. Kegiatan yang dilakukan meliputi pengalaman yang dialami secara langsung selama proses peneltian seperti pencarian sumber, mengkritik sumber, menafsirkan dan menuliskan. Kendala, tantangan dan hal-hal unik yang dialami sejarawan juga merupakan bagian dari pengalaman yang dapat diceritakan.

Latar belakang pendidikan, publikasi ilmiah, dan reputasi sejarawan menjadi pertimbangan sebagai seorang yang berpengalaman. Pengalaman yang diberikan oleh sejarawan dapat membuktikan bahwa sejarah merupakan suatu ilmu yang objektif. Pengalaman tersebut dapat dijadikan dasar pengetahuan bagi peserta didik untuk diadopsi dalam mempraktikan metode penelitian sejarah dengan mengetahui apa yang perlu atau tidak dilakukan dalam penelitian sejarah. Terdapat tiga orang sejarawan dengan latar belakang yang berbeda. Hasil pengamataan dan diskusi dengan sejarawan kemudian diidentifikasi pesan yang disampaikan kepada peserta didik sebagai berikut:

Tabel 2.1

\section{Pesan sejarawan dalam melakukan penelitian sejarah}

\begin{tabular}{|l|l|c|l|l|}
\hline No. & Inisial Sejarawan & $\begin{array}{l}\text { Usia } \\
\text { (tahun })\end{array}$ & Latar Belakang & Pesan \\
\hline 1 & AAR & 26 & $\begin{array}{l}\text { Mahasiswa S2 Ilmu Sejarah } \\
\text { UNPAD }\end{array}$ & $\begin{array}{l}\text { Menulis yang disukai } \\
\text { Fokus permasalahan } \\
\text { Sumber yang relevan }\end{array}$ \\
\hline 2 & HS & 79 & $\begin{array}{l}\text { Guru Besar Pendidikan } \\
\text { Sejarah UPI }\end{array}$ & $\begin{array}{l}\text { Kritis terhadap sumber } \\
\text { Menghargai perbedaan } \\
\text { interpretasi } \\
\text { Belajar bahasa belanda }\end{array}$ \\
\hline 3 & SH & 73 & Guru Besar Sejarah UNPAD & $\begin{array}{l}\text { Berpikir kausalitas } \\
\text { Diksi yang tepat } \\
\text { Berpikir rasional }\end{array}$ \\
\hline
\end{tabular}


HISTORIA: Jurnal Pendidik dan Peneliti Sejarah, 3(1), 11-20. DOI: https://doi.org/10.17509/historia.v3i1.19525.

\section{Keterampilan Penelitian Sejarah di Abad ke-21}

Abad 21 merupakan puncaknya teknologi berkembang di berbagai belahan dunia. Setiap orang memiliki gawai yang dapat digunakan untuk berkomunikasi, menyimpan data dan memperoleh informasi. Setiap individu dapat dengan mudah mengakses berbagai hal termasuk sumber bacaan termasuk berbagai tulisan sejarah, namun hal ini berdampak terhadap mudahnya pengguna internet terkena dampak viral maupun hoax. Berita viral dan hoax tersebut dapat menjadi postif atau negatif tergantung isi berita, dapat pula menjadi bahan provokasi karena ketidakbenarannya. Namun secara menyeluruh dapat dengan mudah tersebar dan memprovokasi netizen atau warga internet. Untuk itu, sebagai netizen harus cerdas dan kritis dalam membaca berita di dunia maya.

Dalam langkah penelitian sejarah yang diawali dengan heuristik, kritik, interpretasi dan historiografi, perlunya sikap peneliti untuk kritis ketika memperoleh sumber. Sikap ini dapat diterapkan dalam kehidupan sehari-hari supaya tidak mudah percaya dan turut serta menyebarkan berita hoax. Justru sebagai pengguna dunia maya, individu dapat berkontribusi dengan menyumbangkan tulisan kritis yang dapat mencegah propaganda terutama yang dapat memecah belah bangsa. Untuk itu, keterampilan penelitian sejarah dapat membantu penyelesaian permasalahan di era digital.

Keterampilan penelitian sejarah atau historical research skills merupakan kemampuan untuk meneliti suatu peristiwa sejarah sehingga siswa memiliki pengalaman belajar secara langsung karena penyelidikan sejarah dilakukan oleh diri sendiri. Penelitian kecil ini dilakukan untuk mencari kebenaran peristiwa sejarah. Maka dari itu dalam proses penyelidikan berdasarkan suatu masalah atau pertanyaan. National Center for the History in the Schools (NCHS) menjelaskan bahwa

"Historical inquiry proceeds with the formulation of a problem or set of questions worth pursuing. In the most direct approach, students might be encouraged to analyze a document, record, or site itself".

Berdasarkan penjelasan tersebut, proses penemuan sejarah yang berawal dari merumuskan masalah akan menganjurkan peserta didik untuk dapat menganalisis sebuah dokumen atau rekaman. Hal ini sependapat dengan penjelasan Ma’mur (dalam Supriatna \& Wiyanarti, 2008, hlm. 201) mengenai cakupan dalam penelitian sejarah yaitu 'memformulasikan pertanyaanpertanyaan sejarah berdasarkan dokumen-dokumen bersejarah, foto-foto, artefak, kunjungan ke situs

Tabel 2.2

Indikator Pencapaian Keterampilan Penelitian Sejarah

\begin{tabular}{|c|c|c|}
\hline $\begin{array}{l}\text { Langkah Penelitian } \\
\text { Sejarah }\end{array}$ & Indikator Pencapaian Keterampilan Penelitian Sejarah & Kode \\
\hline Topik & $\begin{array}{l}\text { Formulate historical question (Merumuskan pertanyaan sejarah) } \\
\text { 1. Peserta didik mampu menentukan tema dalam penelitian } \\
\text { 2. } \quad \text { Peserta didik mampu merumuskan pertanyaan sesuai dengan tema }\end{array}$ & $\begin{array}{l}\mathrm{T} 1 \\
\mathrm{~T} 2\end{array}$ \\
\hline Heuristik & $\begin{array}{l}\text { Obtain historical data (Mendapatkan data sejarah) } \\
\text { 1. Peserta didik mampu menemukan sumber-sumber sejarah yang sesuai } \\
\text { dengan tema } \\
\text { 2. Peserta didik mampu melakukan mengelompokan sumber sejarah }\end{array}$ & $\begin{array}{l}\mathrm{H} 1 \\
\mathrm{H} 2\end{array}$ \\
\hline Kritik & $\begin{array}{l}\text { Interrogate historical data (Memeriksa data sejarah) } \\
\text { 1. Peserta didik mampu melakukan kritik ekternal terhadap sumber } \\
\text { sejarah } \\
\text { 2. Peserta didik mampu membedakan antara fakta dan data } \\
\text { 3. Peserta didik mampu melakukan kritik internal terhadap sumber buku }\end{array}$ & $\begin{array}{l}\text { K1 } \\
\text { K2 } \\
\text { K3 }\end{array}$ \\
\hline $\begin{array}{ll}\text { Interpretasi } & \text { dan } \\
\text { Historiografi } & \end{array}$ & $\begin{array}{l}\text { Support interpretations with historical evidence (Melakukan interpretasi } \\
\text { dengan dukungan bukti sejarah) } \\
\text { 1. Peserta didik mampu menghubungkan hasil temuan dengan } \\
\text { membandingkan pada sumber buku lainnya } \\
\text { 2. Peserta didik mampu membuat historiografi dalam bentuk laporan hasil } \\
\text { penelitian }\end{array}$ & $\begin{array}{l}\mathrm{IH} 1 \\
\mathrm{IH} 2\end{array}$ \\
\hline
\end{tabular}

(Adaptasi : NCHS, 2016)

HISTORIA: Jurnal Pendidik dan Peneliti Sejarah, p-issn:2620-4789 | e-issn:2615-7993 
bersejarah, dan dari kesaksian pelaku sejarah'. Dalam melakukan penelitian sejarah peserta didik akan terlatih kemampuan untuk menggali informasi, mengolah informasi yang kemudian berujung pada kemampuan untuk menulis atau dalam penelitian sejarah disebut historiografi. Peserta didik dapat mengekspresikan pemikirannya melalui tulisan sehingga akan terlihat kemampuan dalam merekontruksi suatu peristiwa sejarah atau tanggapannya terhadap suatu permasalahan. Sebelum melakukan penelitian, peserta didik perlu untuk menentukan tema yang sesuai dengan minatnya. Adapun indikator keterampilan penelitian sejarah dalam penelitian ini dapat dilihat di tabel 2.2

\section{Metode Penelitian}

Penelitian ini menggunakan metode Penelitian Tindakan Kelas (PTK). Pemilihan metode PTK dapat dianggap tepat untuk digunakan dalam penelitian pendidikan, khususnya mengkaji keterampilan penelitian sejarah peserta didik karena menjadikan peneliti dapat mengemukakan ide/ gagasan untuk mengambil keputusan dalam pembelajaran sejarah untuk dikembangkan menjadi lebih baik. Tujuan dasar Penelitian Tindakan Kelas adalah memperbaiki praktek pembelajaran guru di kelas atau dosen di ruang perkuliahan, dan bukan untuk menghasilkan pengetahuan atau teori (Wiriaatmadja, 2014, hlm. 75). Hal ini diperkuat oleh pendapat Supriatna (2007, hlm. 190) yang mengatakan bahwa Penelitian Tindakan Kelas (PTK) merupakan salah satu jenis penelitan pendidikan yang dapat digunakan oleh guru sejarah untuk meningkatkan kualitas pembelajaran di kelas. Perlunya melakukan inovasi dalam pembelajaran dalam mengatasi permasalahan tersebut melalui PTK. Disinilah perlunya PTK untuk melahirkan inovasi-inovasi pembelajaran yang efektif dan menyenangkan sehingga memudahkan peserta didik mencapai standar kompetensi dan kompetensi dasar yang telah ditetapkan (Mulyasa, 2011, hlm. 54). Penelitian ini dilakukan di kelas X IPS 1 SMAN 3 Bandung yang berjumlah 23 orang, pemilihan lokasi ini karena hasil observasi memperlihatkan bahwa peserta didik memiliki semangat belajar dan kemampuan literasi yang baik namun tidak kritis. Kritis ini dapat dilatih melalui keterampilan penelitian sejarah.

Desain PTK yang digunakan dari Elliot dengan langkah yang dilakukan identifikasi ide awal, reconnaissance, rencana umum, implementasi, dan implementasi tahap selanjutnya (Elliot, 1991). Pada tahap identifikasi ide awal dilakukan penentuan ide umum yang menjadi fokus permasalahan yang dalam penelitian ini terlihat bahwa materi penelitian sejarah masih terbatas pada pengetahuan. Reconnaissance dilakukan dengan mengumpulkan fakta yang dibutuhkan dengan menjelaskan hubungannya seperti menguraikan kegiatan peserta didik dicatat dalam catatan lapangan yang dihubungkan dengan kondisi ideal. Kemudian dilakukan rencana umum dengan menyusun RPP yang tidak hanya memperhatikan pengetahuan, melainkan keterampilan penelitian sejarah yang dituangkan dalam indikator pencapaian. Selanjutnya, RPP yang telah disusun diimplementasikan dalam proses pembelajaran yang kemudian akan memutuskan tindakan yang tepat pada implementasi tahap selanjutnya. Pada tahap terakhir tersebut, dilakukan refleksi tindakan yang telah dilaksanakan di kelas melalui pemanfaatan sejarawan sebagai sumber belajar. Ketika masih terdapat kekurangan, maka ditinjau kembali pada tahap reconnaissance kemudian perbaikan tersebut diterapkan pada langkah selanjutnya yaitu rencana umum dan implementasi. Upaya perbaikan ini diperlukan demi tercapainya tujuan yaitu mengenai peningkatan keterampilan penelitian sejarah peserta didik.

Guru dalam PTK merupakan mitra dari peneliti yang membantu peneliti untuk memperbaiki proses pembelajaran. Kegiatan kolaborasi dalam PTK merupakan keharusan karena peneliti dan mitra saling membutuhkan satu sama lain. Mitra bertugas untuk mencatat hal-hal penting selama proses pengamatan. Catatan tersebut menjadi bahan diskusi antara mitra dengan peneliti untuk menyepakati tindakan selanjutnya, apakah dianggap cukup atau masih ada yang harus diperbaiki.

Teknik pengumpulan data yang dilakukan peneliti melalui observasi, wawancara, studi dokumentasi, dan evaluasi hasil belajar. Observasi yang dilakukan untuk menggambarkan secara keseluruhan proses pembelajaran. Wawancara dilakukan terhadap peserta didik untuk memperoleh pandangannya terhadap pelajaran sejarah dan dampak dari pembelajaran dengan mendatangkan sejarawan. Wawancara dilakukan di ruang guru, depan kelas dan taman supaya peserta didik merasa nyaman ketika diwawancara oleh peneliti sehingga dapat menggali informasi lebih mudah. Studi dokumentasi dilakukan dengan mengarsipkan RPP dan foto sebagai bukti penelitian yang dilakukan. Evaluasi menggunakan tes hasil belajar digunakan untuk mengetahui aspek pengetahuan peserta didik. Sedangkan laporan hasil penelitian untuk mengukur pencapaian aspek keterampilan peserta didik.

\section{Proses Meningkatkan Keterampilan Penelitian Sejarah}

Tindakan yang dilakukan dalam penelitian disesuaikan dengan kebutuhan yang terjadi dilapangan. 
HISTORIA: Jurnal Pendidik dan Peneliti Sejarah, 3(1), 11-20. DOI: https://doi.org/10.17509/historia.v3i1.19525.

Proses peningkatan keterampilan dilihat dengan mengacu pada tabel 1.2 dengan kategori Baik-CukupKurang pada setiap indikator. Kategori B untuk sebagian besar peserta didik telah menunjukkan kemampuan yang diharapkan. Kategori C untuk jumlah peserta didik yang menunjukkan kemampuan yang diharapkan sama dengan jumlah peserta didik yang belum. Kategori $\mathrm{K}$ untuk sebagian kecil peserta didik yang telah menunjukkan kemampuan yang diharapkan. Untuk memperkuat keterampilan peserta didik diperlukan data pendukung pengetahuan yang dilihat dari tes hasil belajar yang dilakukan pada setiap tindakan. Terdapat tiga siklus dengan tujuh tindakan dengan uraian sebagai berikut:

\section{Siklus Satu}

Siklus satu bertujuan untuk mengembangkan pengetahuan awal peserta didik mengenai penelitian sejarah. Peneliti bersama guru sepakat dalam siklus ini untuk menguraikan langkah-langkah melakukan penelitian sejarah sebagai pengantar pengetahuan peserta didik sebelum mempraktekan keterampilan tersebut.

\section{Tindakan ke-satu}

Kegiatan pembelajaran pada tindakan kesatu menggunakan model inquiry learning. Ketika guru menanyakan tentang "mengapa perlu dilakukan penelitian?" $\mathrm{R}$ dan $\mathrm{S}$ menjawab untuk mengetahui kebenaran. Lebih lanjut guru menanyakan tentang "manakah yang lebih tua antara Gunung Padang atau peradaban di Mesir?" terdapat tiga orang peserta didik bernama $H, L, G$ yang menjawab bahwa sumber informasi tentang Gunung Padang masih perlu dikaji lagi. Pemahaman awal peserta didik sudah ada tentang pentingnya melakukan penelitian. Namun belum secara menyeluruh sehingga pencapaian indikator pada tabel 1.2 termasuk ke dalam kategori kurang. Sedangkan ratarata hasil tes pada tindakan ini yaitu 65 . Upaya yang perlu ditingkatkan kembali pada siklus selanjutnya adalah memotivasi peserta didik untuk membuka wawasan dalam memahami peristiwa sejarah berdasarkan sumber yang valid dan reliabel.

\section{Tindakan ke-dua}

Pada pertemuan kali ini terfokus pada penentuan tema penelitian, peserta didik dibagi kedalam lima kelompok yang hasilnya mengangkat judul Sejarah Kota Bandung, Bandung Lautan Api, Sejarah SMAN 3 dan 5 Bandung, Konperensi Asia Afrika, APRA dan Bandung Tempo Dulu. Terdapat tiga dari lima kelompok yang sudah bisa menentukan judul penelitan. Sehingga untuk indikator T1 masuk kategori cukup dan yang lainnya kurang. Rata rata nilai peserta didik meningkat menjadi 76. Adanya peningkatan hasil belajar dan pemahaman peserta didik sehingga fokus pada tindakan selanjutnya adalah keterampilan dalam melakukan penelitian sejarah.

\section{Siklus Dua}

Berdasarkan hasil dari siklus sebelumnya, fokus utama di siklus kedua adalah menghadirkan sejarawan sebagai sumber belajar. Tindakan yang dilakukan sebanyak tiga kali dengan setiap tindakannya terdapat sejarawan untuk membagikan pengalamannya dalam melakukan penelitian sejarah.

Tindakan ke-tiga

Sejarawan yang dihadirkan pada tindakan ketiga berinisial AAR yang menceritakan pengalamannya dalam menulis sejarah yang menurutnya harus sesuai dengan ketertarikan peneliti terhadap suatu topik. Selama proses pembelajaran, tergambarkan seluruh peserta didik menghadapi kesulitan dalam melakukan merumuskan masalah. Selanjutnya diceritakan bahwa ketika AAR melakukan penelitian tentang peristiwa 27 Juli 1996 perlu untuk mencari sumber referensi dahulu kemudian kita memiliki pemahaman tentang peristiwa tersebut sehingga dapat dengan mudah merumuskan masalah. Upaya AAR dalam mencari sumber dengan mengunjungi Perpustakaan Nasional di Jakarta untuk mencari koran. Saat proses pencariaan informasi ditemukan hal unik yaitu terdapat tagline iklan 'Diboeka Kleermaker' yang artinya tukang jahit. Padahal tahun 1996 namun masih menggunakan bahasa belanda, sehingga peneliti harus bisa memilah informasi yang sesuai dengan topik. Oleh karena itu, perlu untuk fokus pada permasalahan penelitian dan menggunakan sumber yang relevan. Selanjutnya LE menanyakan tentang cara mengkritik sumber lisan. $\mathrm{R}, \mathrm{L}$ dan $\mathrm{H}$ yang menanyakan tentang cara mengkritik sumber foto dan sumber yang berbahasa belanda. Hasil observasi dapat dikategorikan T1 telah mencapai Baik. Sedangkan T2, H3 dan K1 Cukup, serta yang lainnya masih pada kategori kurang. Hasil belajar menunjukkan adanya peningkatan menjadi rata-rata 80 . Pada tindakan ketiga terlihat penggunaan sumber yang relevan dan kritis terhadap sumber masih perlu ditingkatkan.

Tindakan ke-empat

Pelaksanaan tindakan ini dengan melakukan kunjungan ke rumah sejarawan berinisial HS dengan dihadiri lima orang sebagai perwakilan kelompok, akan tetapi satu orang berhalangan hadir. Selama proses konsultasi terkait penelitian sederhana yang dilakukan masing-masing kelompok, HS menceritakan pengalamannya ketika mencari sumber terkait kesultanan di Kalimantan Selatan dan Tengah ke arsip di Den Haag, perlu untuk memahami bahasa 
belanda karena yang dilakukannya menterjemahkan ke bahasa inggris lalu ke bahasa Indonesia. Apabila kita sudah memahami bahasa belanda akan sangat membantu dalam menelusuri sumber. Seorang peserta didik berinisial $\mathrm{R}$ menceritakan kegiatan yang sudah dilakukan dalam pencarian sumber tentang SMAN 3 dan 5 Bandung, namun terdapat kebingungan ketika dihadapkan pada perbedaan antara fakta dan data. Secara ringkas S menjelaskan bahwa data itu kumpulan fakta yang belum diolah, sedangkan fakta sesuatu yang benar. HS mengapresiasi jawaban tersebut dan menjelaskan bahwa kritik sumber bertujuan untuk mengambil faktafakta yang dibutuhkan peneliti. Selanjutnya R bertanya tentang praktek dari interpretasi, hal ini menyiratkan bahwa peserta didik belum memahami konsep yang abstrak. HS menunjukkan gambar untuk ditafsirkan yang menjadikan A dan $\mathrm{R}$ berbeda pendapat. Menurut A gambar yang dimaksud adalah dua wajah yang saling berhadapan, $\mathrm{R}$ menjawab gambar tersebut adalah dua bua gelas. HS menengahi kondisi ini dengan memberikan analogi: 'Sultan Hamid II yang merupakan keturunan sultan dari Pontianak tapi kenapa tidak menjadi pahlawan nasional? Karena terlibat dengan Westerling padahal dia yang merumuskan lambang negara kita”. Hal tersebut merupakan salah satu tafsir karena untuk mengangkat seseorang menjadi pahlawan nasional itu sulit dan berbeda-beda interpretasi merupakan hal yang wajar dikalangan sejarawan. Berdasarkan tabel 1.2 tentang sejarah kota atau kabupaten. Ketika seluruh kelompok presentasi memaparkan hasil temuannya, terdapat 2-3 orang dari setiap kelompok yang menjawab pertanyaan dariSH terkait hasil temuan penelitiannya. $\mathrm{SH}$ menyimpulkan bahwa peserta didik sudah bisa mencari sumber buku, foto dan arsip yang relevan namun belum tergambarkan berpikir secara rasional dan kausalitas karena menurut $\mathrm{SH}$ sejarah tidak bisa terlepas dari sebab-akibat yang bisa tercapai jika berpedoman kepada $5 \mathrm{~W}+1 \mathrm{H}$. SH memberikan contoh dengan penentuan hari jadi Bandung yang tidak bisa secara tiba-tiba langsung menentukan tanggalnya tetapi ada persitiwa yang menjadi sebab dan akibatnya berdirilah Bandung. Pemilihan redaksi dalam penulisan harus diperhatikan agar tidak mengundang/mengandung pertanyaan. $\mathrm{SH}$ memberikan perumpamaan dengan "Apa arti dari asal kata Bandung?" Ketika D menjawab 'ngabandeng, E menjawab 'bendungan'. Selanjutnya SH menceritakan hasil penelusurannya tentang peninggalan bersejarah dari Padalarang sampai Cicalengka ada sekitar $30 \mathrm{~km}$, Tangkuban Perahu dari arah utara sampai ke Soreang di selatan merupakan bendungan yang luas pesisirnya adalah Padalarang. Kunjungan ke lapangan sangat baik dilakukan untuk memperoleh gambaran secara utuh sehingga tidak terpaku hanya pada buku.

Pada akhir pembelajaran SH berkata "Sejarawan itu pekerjaan yang bagus karena pasti punya pekerjaan, dengan kalian telah membuat karya tulis seperti ini juga

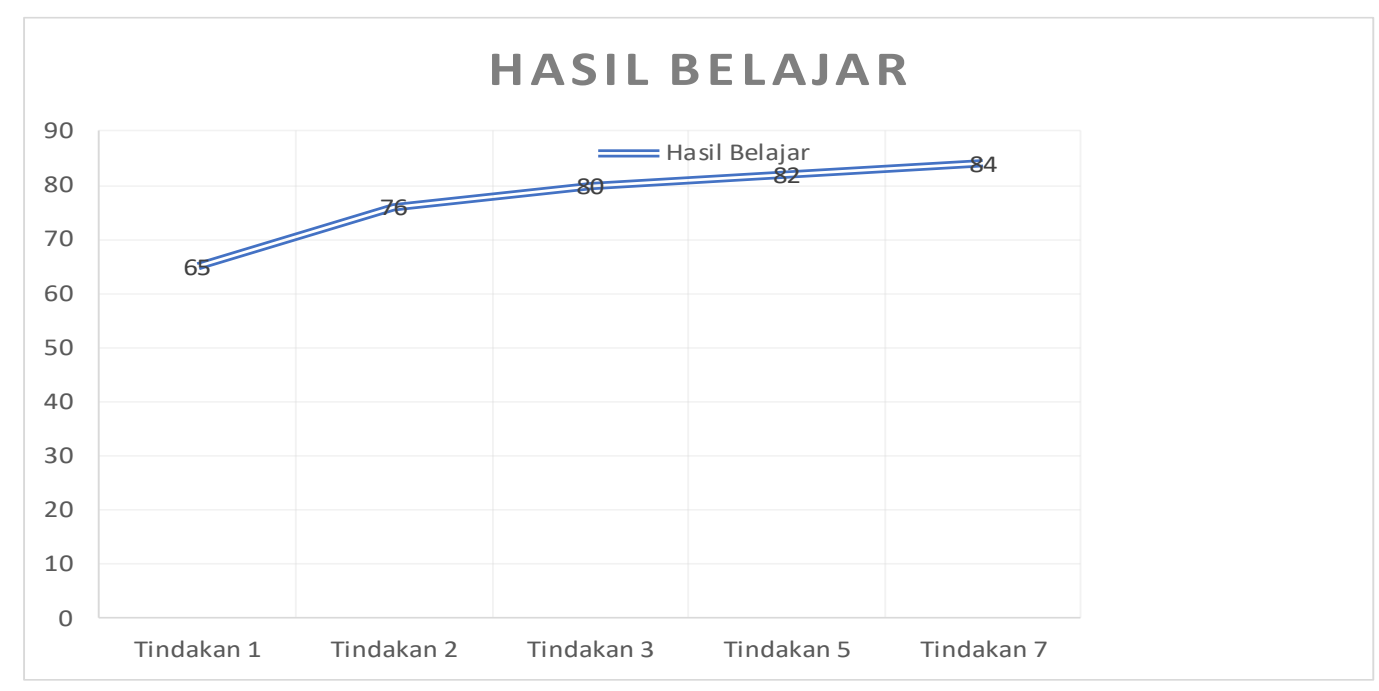

Gambar 1.1 Peningkatan Hasil Belajar Peserta Didik

menunjukkan T1 dan T2 Baik, H2, IH1, IH2 Kurang dan selebihnya pada kategori Cukup.

Tindakan ke-lima

Pada tindakan ke-lima SH hadir sebagai sejarawan yang banyak memiliki pengalaman dalam menuliskan berarti kalian telah menjadi sejarawan dan tingkatkan lagi membaca dan harus kritis". Hal tersebut memberikan penguatan dan semangat kepada peserta didik untuk mengerjakan laporan hasil penelitian sebaik mungkin. Keterampilan peserta didik untuk T1, T2, H1, dan K1

HISTORIA: Jurnal Pendidik dan Peneliti Sejarah, p-issn:2620-4789 | e-issn:2615-7993 
HISTORIA: Jurnal Pendidik dan Peneliti Sejarah, 3(1), 11-20. DOI: https://doi.org/10.17509/historia.v3i1.19525.

telah mencapai Baik, H2, K2, dan K3 Cukup, IH1 dan IH2 masih pada kategori kurang. Hasil belajar yang dicapai peserta didik rata-rata sebesar 82 .

\section{Siklus Tiga}

Setelah menunjukkan adanya kemampuan awal dalam mengumpukan dan mengkritik sumber telah tercapai. Maka diperlukan siklus tiga untuk mengetahui pencapaian peserta didik saat menginterpretasikan dalam menulis sejarah dalam bentuk laporan hasil penelitian atau disebut juga historiografi. Terdapat dua tindakan pada siklus tiga.

Tindakan ke-enam

Proses pembelajaran kali ini terfokuskan pada penyusunan laporan hasil penelitian sederhana yang dilakukan oleh peserta didik. Terdapat kelompok yang terinspirasi dari pertemuan sebelumnya untuk melakukan kunjungan langsung ke situs bersejarah. Seperti yang dilakukan oleh kelompok Bandung Lautan Api melakukan kunjungan ke stilasi yang terletak di alun-alun kota Bandung dengan tujuan dapat merekontruksi secara jelas peristiwa Bandung Lautan Api tahun 1946. Hal ini dilakukan juga oleh kelompok KAA yang berkunjung ke Museum Konperensi Asia Afrika dan perpustakaannya. MR sebagai perwakilan dari kelompok Bandung Tempo Dulu berkunjung ke jalan Braga untuk membandingkan kondisi Bandung masa kolonial dengan saat ini. Kelompok SMAN 3 dan 5 Bandung telah menemukan foto sekolah ketika masih HBS yang telah dimasukan kedalam laporan. Sedangkan kelompok APRA tidak mengalami kendala karena telah mengunjungi perpustakaan TNI-AD yang dekat dengan sekolah. Kunjungan yang dilakukan oleh setiap kelompok atas inisiatif sendiri yang terinspirasi dari sejarawan. Keterampilan yang telah dicapai oleh peserta didik untuk indikator IH1 dan IH 2 Cukup dan yang lainnya telah pada kategori Baik.

Tindakan ke-tujuh

Metode yang digunakan yaitu presentasi laporan hasil penelitian sederhana dengan sistem pararel. Pada pertemuan ini telah menunjukkan adanya kemampuan peserta didik dalam menyusun laporan hasil penelitian terbukti dari sistematika penulisan telah sesuai dengan kaidah yang berlaku. Hal ini menunjukkan adanya pencapaian keterampilan peserta didik dalam menyusun historiografi secara sederhana. Selain itu seluruh indikator telah mencapai kategori Baik dan rata-rata nilai peserta didik adalah 84 . Tindakan ketujuh merupakan siklus terakhir karena pada siklus ini terlihat telah mencapai titik jenuh terbukti dari aktivitas peserta didik tidak ada perubahan yang berarti.
Berdasarkan gambar bagan 2.1 menunjukkan adanya peningkatan hasil belajar pada setiap tindakan. Selain melalui hasil belajar dan laporan hasil penelitian, peneliti juga melakukan wawancara terhadap lima orang peserta didik dengan pertanyaan: 1) Manfaat apa yang diperoleh dengan belajar pada Sejarawan; 2) Apakah ada keinginan untuk menjadi seorang sejarawan pada masa yang akan datang?; 3) Menurut Anda, siapa yang lebih baik dalam memberi pengalaman penelitian sejarah?.

Persepsi peserta didik yang merasa sudah masuk sekolah terbaik di kota Bandung memunculkan sifat arogan dengan merasa ahli dalam segala bidang dan menyepelekan yang lain. Hasil wawancara menunjukan hal yang menarik, meskipun peserta didik tidak ingin menjadi sejarwan di masa yang akan datang. Namun memunculkan kesadaran bahwa pelajaran sejarah bukan pelajaran yang dianggap sebelah mata. Sejarawan yang memperoleh gelar Doktor di luar negeri menginspirasi peserta didik untuk dapat bersekolah di luar negeri untuk mencapai cita-cita serta menyadarkan bahwa ilmu yang saat ini diperoleh masih sedikit sehingga perlu untuk lebih kritis dan giat dalam belajar. Melatih bahasa asing selain bahasa inggris juga merupakan suatu kebutuhan bagi peserta didik. Setiap sejarawan memiliki gestur yang khas saat proses pembelajaran dengan peserta didik, seperti AAR yang tenang dalam menjelaskan namun menggunakan bahasa ilmiah yang terkadang tidak dipahami oleh peserta didik, HS yang memberikan contoh rill sehingga mudah dipahami, $\mathrm{SH}$ yang memiliki intonasi suara tinggi dalam menceritakan pengalamannya namun menjadikan anak memahami pentingnya kritis saat menemukan sumber. Gestur ini mempengaruhi sikap peserta didik ketika berinteraksi dengan sejarawan menjadi berani atau tidak untuk bertanya. Secara menyeluruh peserta didik menyukai cara kerja sejarawan dalam melakukan penelitian.

\section{Simpulan}

Simpulan yang diperoleh dari hasil penelitian sebagai berikut, Pertama, penyebab peserta didik belum memiliki keterampilan penelitian sejarah karena dalam kegiatan belajar mengajar masih sebatas pada pengetahuan belum kepada keterampilan. Selain itu, pembelajaran belum berpusat pada peserta didik. Sehingga pandangan peserta didik mengenai pelajaran sejarah yang dianggap membosankan akan berubah. Kedua, RPP yang disusun menggunakan metode inquiry learning dengan mendatangkan/mengunjungi sumber belajar yaitu sejarawan. RPP tersebut sesuai dengan kurikulum 2013, di mana tidak hanya ranah kognitif yang dikembangkan melainkan keterampilan. Pembelajaran 
sejarah dengan mendatangkan/mengunjungi sejarawan yang memiliki karakter dan latar belakang pendidikan dari lulusan yang berbeda-beda memberikan motivasi peserta didik untuk berpikir kausalitas dan kritis dalam membaca. Selain itu, memberikan kesadaran kepada peserta didik bahwa pelajaran sejarah bukan pelajaran yang dapat dinomor duakan. Ketiga, hasil belajar peserta didik jika dilihat dari hasil tes menunjukkan adanya peningkatan. Sedangkan hasil laporan hasil penelitian terlihat adanya perubahan keterampilan peserta didik, yang awalnya belum memahami cara membuat laporan menjadi bisa untuk mensitasi sumber, menghubungkan antar fakta menjadi satu narasi dan menyusun laporan penelitian sejarah disebut historiografi. Keempat, kendala yang dihadapi dalam melatih keterampilan peserta didik diperlukan waktu yang lebih banyak lagi karena perlu adanya pengulangan secara berkala agar peserta didik terbiasa melakukan penelitian. Namun secara keseluruhan para sejarawan telah memberikan dampak positif dengan memotivasi dan menginspirasi peserta didik.

\section{REFERENSI}

Cuttica, C. (2019). Archaeologist, coroner, detective, lawyer, translator or what? the (intellectual) historian, cultural criticism, audiences and the painterly eye. Global Intellectual History, 6(5), 573591. 10.1080/23801883.2019.1655520

Elliot, J. (1991). Action research for educational change developing and teaching. University Press

Gottschalk, L. (1985). Mengerti Sejarah. Jakarta: Universitas Indonesia

Haigh, N. (2012) Historical research and research in higher education: reflections and recommendations from a self-study. Journal Higher Education Research \& Development, 31(5), 689-702. 10.1080/07294360.2012.689955

Hasan, S. H. (2012). Pendidikan sejarah indonesia : Isu dalam ide dan pembelajaran. Bandung : Rizqi Press.
Korzenik, D. (1985). Doing historical research. Journal Studies in Art Education, 26(2), 125-129. 10.1080/00393541.1985.11650409

McCully, A. (2012). History teaching, conflict and the legacy of the past. Education Citizenship and Sosial Justice, 7(2), 145-159. https://doi. org/10.1177/1746197912440854

Mulyasa. (2011). Praktik penelitian tindakan kelas. Bandung : PT Remaja Rosdakarya

National Center for the History in the Schools.(t.t.). Historical thinking. Diakses dari: http://www. nchs.ucla.edu/history-standards/standards-forgrades-k-4/historical-thinking-standards/4.historical-research-capabilities

Purwanto, B. (2001). Historisisme baru dan kesadaran dekonstruktif: kajian kritis terhadap historiografi indonesiasentris. Jurnal Humaniora, 8(1), 29-44.

Rahayu, W. (2019). Pembelajaran Sejarah untuk Generasi Z. Jurnal Pendidikan Sejarah Indonesia, 2(1), 1-7.

Sanjaya, W. (2012). Strategi pembelajaran berorientasi standar proses pendidikan. Jakarta : Kencana

Sjamsuddin, H. (2007). Metodologi sejarah. Yogyakarta :Ombak.

Supriatna, N. (2007). Konstruksi pembelajaran sejarah kritis. Bandung: Historia Utama Press

Supriatna, N \& Wiyanarti, E. (Editor). (2008). Sejarah dalam keberagaman. Bandung: Jurusan Pendidikan Sejarah FPIPS UPI.

Viator, M G. (2012). Developing Historical Thinking through Questions, Journal The Social Studies, 103(5), 198-200. 10.1080/00377996.2011.606438

Wiriaatmadja, R. (2002). Pendidikan sejarah di indonesia: perspektif lokal, nasional, dan global. Bandung: Historia utama press

Wiriaatmadja, R. (2014). Metode penelitian tindakan kelas: untuk meningkatkan kinerja guru dan dosen. Bandung : PT Remaja Rosdakarya. 